\title{
THE TREATMENT OF MARRIED WOMEN BY THE SOCIAL SECURITY RETIREMENT PROGRAM
}

\author{
Andrew G. Biggs, Gayle L. Reznik, and Nada O. Eissa
}

CRR WP 2010-18

Date Submitted: October 2010

Date Released: November 2010

\author{
Center for Retirement Research at Boston College \\ Hovey House \\ 140 Commonwealth Avenue \\ Chestnut Hill, MA 02467 \\ Tel: 617-552-1762 Fax: 617-552-0191 \\ http://crr.bc.edu
}

Andrew G. Biggs is a resident scholar at the American Enterprise Institute (AEI). Gayle L. Reznik is with the Office of Retirement Policy, Office of Retirement and Disability Policy, Social Security Administration (SSA). Nada O. Eissa is an associate professor of Public Policy and Economics at Georgetown University (GU). The research reported herein was pursuant to a grant from the U.S. SSA funded as part of the Retirement Research Consortium (RRC). The findings and conclusions expressed are solely those of the authors and do not represent the opinions or policy of SSA, any agency of the federal government, the RRC, AEI, GU, or Boston College.

(C) 2010, by Andrew G. Biggs, Gayle L. Reznik, and Nada O. Eissa. All rights reserved. Short sections of text, not to exceed two paragraphs, may be quoted without explicit permission provided that full credit, including (C) notice, is given to the source. 


\title{
About the Center for Retirement Research
}

The Center for Retirement Research at Boston College, part of a consortium that includes parallel centers at the University of Michigan and the National Bureau of Economic Research, was established in 1998 through a grant from the Social Security Administration. The Center's mission is to produce first-class research and forge a strong link between the academic community and decision makers in the public and private sectors around an issue of critical importance to the nation's future. To achieve this mission, the Center sponsors a wide variety of research projects, transmits new findings to a broad audience, trains new scholars, and broadens access to valuable data sources.

\author{
Center for Retirement Research at Boston College \\ Hovey House \\ 140 Commonwealth Avenue \\ Chestnut Hill, MA 02467 \\ phone: 617-552-1762 fax: 617-552-0191 \\ e-mail: crr@bc.edu \\ http://crr.bc.edu/
}

Affiliated Institutions:

The Brookings Institution

Massachusetts Institute of Technology

Syracuse University

Urban Institute 


\begin{abstract}
Policy Abstract
It is generally accepted that the Social Security program pays women a higher average ratio of lifetime benefits to lifetime taxes than it does men. Social Security's progressive benefit structure and annuity payment combine with women's lower average earnings and longer average life spans to provide women with more favorable treatment on a lifetime basis. This more favorable treatment does not necessarily imply that women are presented with stronger incentives to participate in the labor force and contribute to Social Security than are men. If anything, Social Security does the opposite. The auxiliary benefit provisions, including spousal and widow's benefits, mean that many women do not receive higher benefits in return for their contributions than they would have received had they never worked or contributed to the program. In this paper, we calculate two measures of treatment by Social Security using the SSA's Modeling Income in the Near Term (MINT) micro-simulation model: the net tax rate, which reflects the net value of Social Security taxes and benefits as a percentage of lifetime earnings; and the generated net tax rate, which represents the net value of benefits received in return for a participant's taxes relative to lifetime earnings. While women pay low and even negative average net taxes to Social Security, their generated net tax rates are higher and often equal the full statutory tax rate. Men, by contrast, pay higher net tax rates but lower generated net tax rates, as their earnings may generate additional benefits for their spouse or survivor. The work incentives presented by Social Security may differ significantly from those implied by measures of overall treatment by the program.
\end{abstract}




\section{Introduction}

The distributional effects of the Social Security program have long been of interest to policy analysts and policymakers, alike. The existing body of work shows the program redistributes across income and demographic characteristics (race and gender). More recent analyses have benefited from the increased sophistication of microsimulation models of the Social Security population. ${ }^{1}$ For example, such analyses have showed favorable treatment of married women by the Social Security program. Married women have lower average-lifetime earnings than both men and single women, and therefore benefit from the progressivity of the benefit formula. They also tend to have longer-than-average life spans, and therefore benefit from the annuity structure of benefit payments. Finally, married women - and divorced women who had a previous marriage that lasted at least 10 years - are eligible to receive Social Security spousal and survivors benefits, likely increasing their benefit payments above those based on their own earnings records. ${ }^{2}$

All of these factors combine to provide married women with a better "money's worth" from Social Security than many other demographic groups. Money’s worth measures often include the internal rate of return, the ratio of lifetime benefits to lifetime taxes, and the net tax rate, which equals the net of taxes and benefits as a percentage of lifetime earnings.

There has also been increased attention in recent years to the work incentives presented to different demographic and age groups by the Social Security program. Social Security is funded by a 12.4 percent tax on earned income up to an annual maximum (currently $\$ 106,800$ ) that increases with average wage growth each year. The tax is split evenly between employers and employees, though there is a general consensus that employees bear most or all of the tax through reduced wages. ${ }^{3}$

Unlike most other federal taxes, however, there is a fairly direct link between Social Security payroll taxes paid and benefits received. The terminology of Social Security “contributions" is useful, because a tax that directly generates a benefit should not affect labor supply incentives in the same way as a "pure tax" for which no direct benefits are received. The

\footnotetext{
${ }^{1}$ For instance, see Gustman and Steinmeier, 2000; Smith, Toder and Iams, 2004.

${ }^{2}$ Cohen, Steuerle and Carasso, 2004.

${ }^{3}$ For instance, Congressional Budget Office (2005) states, "Public finance theorists generally agree that the employer's share of [payroll] taxes is passed on to workers in the form of lower wages. CBO follows that assumption and treats payroll taxes as if employees paid both shares.”
} 
relevant measure from the point of view of labor supply incentives is the net-of-benefits tax rate, often referred to as the "net tax rate."

Recent research has focused on work incentives along various margins, in which the link between contributions, earnings, and benefits is examined in greater detail. ${ }^{4}$ These margins include annual hours worked (intensive response); participation in the labor force in a given year (extensive response); or, labor force participation on a lifetime basis by the spouse with the lower-earning potential. In many or most cases, overall treatment by Social Security as measured by traditional money’s worth measures accurately reflects the Social Security program’s marginal incentives to work.. Among single individuals, for instance, lower-income earners can expect a higher ratio of lifetime benefits to lifetime taxes - and thus a lower net tax rate - than high-income earners.

Among married couples - particularly women - however, lifetime money’s worth measures may not present a full picture of the incentives presented by the Social Security program. This disjoint occurs because of the presence of auxiliary benefits - specifically, spousal and widow's benefits - in which one individual may claim benefits off the earnings record of a second individual. In these cases, higher individual earnings may not result in greater benefits, thereby weakening incentives to work and increasing effective net tax rates. Many married women fall into this category. Others, however, gain from this benefit structure. In cases where one's earnings generate benefits both for that individual and for a spouse (or, on a delayed basis, for a widow), effective net tax rates may be significantly lower than those implied by traditional money’s worth measures.

In this analysis, we use a microsimulation model of the Social Security population, augmented by historical and projected data, to analyze the impact of Social Security's auxiliary benefit provisions on the work incentives of married women. The Social Security Administration (SSA)'s Modeling Income in the Near Term (MINT) model allows for detailed analysis of the earnings, benefits, and demographic characteristics of individuals participating in the Social Security program. Using MINT data, we calculate both statutory net-tax rates, and a measure we term the "generated" net-tax rate. The generated rate reflects the net Social Security tax rate based upon a wife's own tax contributions during her working life. The generated and statutory net-tax rates differ because of spousal and widow benefits.

\footnotetext{
${ }^{4}$ See Goda, Slavov and Shoven (2007); Butrica et al (2004); Reznik, Weaver and Biggs (2009).
} 
The paper proceeds as follows. First, we outline the basics of the Social Security benefit formula, including discussion of auxiliary benefits for spouses and widows. Second, we introduce the measures of the net tax rate and the generated net tax rate. Third, these net tax rate measures are illustrated using stylized earnings patterns. Fourth, we provide background on the MINT model used in our detailed analysis. Fifth, we discuss the results of the analysis using the MINT model showing how incentives differ between different groups within a given birth cohort and how such incentives evolve over different birth cohorts. Sixth, we conclude with remarks on further research and policy implications.

\section{Background on the Social Security benefit formula}

Social Security provides a progressive replacement of lifetime earnings, such that lowerearning individuals receive a higher ratio of benefits to pre-retirement earnings (or "replacement rate") than do higher-earning individuals. Within the historical background of the program, Social Security is designed to combine "equity" and "adequacy.” Equity is the idea that benefits are based upon earnings in order to differentiate Social Security from a "welfare program" and to remove any stigma from receipt of benefits. Adequacy is the intent to provide higher benefits relative to earnings for lower earners in order to reduce the possibility of inadequate incomes in retirement or other periods of benefit receipt.

Social Security is funded through a payroll tax on earned income up to an annual maximum (currently $\$ 106,800$ ). These tax payments, however, are only indirectly linked to benefits. The payroll tax is levied, during working years, on earned income while, at retirement, benefits are calculated based upon lifetime earned income. This implies that higher earnings would in general produce an entitlement to higher benefits, though a higher payroll tax rate would not.

The Social Security benefit calculation follows a number of steps. ${ }^{5}$ First, an individual's past earnings are indexed to the growth of wages through age 60 . This involves multiplying the ratio of earnings in a past year to average wages economy-wide in that year by the average wage in the year the worker turned 60. For instance, an individual who earned half the average wage in

\footnotetext{
${ }^{5}$ For more information see Social Security Administration (2010).
} 
a prior year would have those earnings indexed to half the average wage as of the year he turned 60. Earnings past age 60 are not indexed.

Next, Social Security averages the highest 35 years of indexed earnings, then divides by 12 to calculate the individual's Average Indexed Monthly Earnings (AIME). The AIME is then run through a progressive benefit formula to produce the Primary Insurance Amount (PIA) payable at the full retirement age, currently 66. For example, the basic benefit formula for a worker who first becomes eligible to receive benefits in 2010 is:

(a) 90 percent of the first $\$ 761$ of average indexed monthly earnings; plus

(b) 32 percent of average indexed monthly earnings between $\$ 761$ and $\$ 4,586$; plus

(c) 15 percent of average indexed monthly earnings over $\$ 4,586 .^{6}$

These dollar amounts, referred to as "bend points," are indexed annually to the growth of average wages.

The basic benefit (called the primary insurance amount or PIA) is the amount paid if benefits are claimed at the full retirement age. After claiming, benefits are increased annually along with the Consumer Price Index for Urban Wage Earners and Clerical Workers (CPI-W). The PIA is reduced or increased based on the age at which the individual claims benefits. Benefits are reduced by 5/9ths of 1 percent per month for the first 36 months benefits are claimed prior to the full retirement age, currently age 66, and 5/12 of 1 percent for each additional month. For individuals born in 1943 and later, benefits are increased by 8 percent for each year the individual delays claiming past the full retirement age. ${ }^{7}$ In general, adjustments for early and delayed retirement are actuarially fair, such that the present value of expected lifetime benefits remains roughly constant regardless of the age at which benefits are claimed.

\footnotetext{
${ }^{6}$ Only earnings up to the maximum taxable amount in each year are used in the basic benefit formula. In 2010, the maximum taxable amount is $\$ 106,800$ and the maximum benefit for a worker retiring at the full retirement age is \$2,346 per month.

${ }^{7}$ The full retirement age is increasing two months per year from sixty-five to sixty-seven years of age. The full retirement age is currently scheduled to remain at sixty-seven for all individuals born in 1960 or later. A full explanation of this change can be found at: http://www.ssa.gov/retire2/retirechart.htm.
} 
However, the benefit formula is generally not actuarially fair with regard to additional earnings that may accrue due to delayed retirement. ${ }^{8}$

This picture is complicated for married couples, where the lower-earning spouse may be eligible to receive an auxiliary benefit based upon the earnings of the higher-earning spouse. Social Security spousal benefits are gender-neutral. However, in most cases the wife is the recipient of spousal benefits. A married person or a divorced person (who was married to the worker for at least 10 years) can receive a benefit equal to 50 percent of the spouse's or exspouse's PIA if benefits are claimed at the full retirement age. Importantly, an individual may receive the higher of her own earned benefit or a spousal benefit, but not both.

Currently, around 15 percent of retired women receive only a spousal benefit, meaning that they are not qualified for a retirement benefit based upon their own earnings. Of the approximately 85 percent of women who are qualified for their own retired worker benefit, around 36 percentage points consist of dually entitled women who receive a spousal benefit in addition to benefits based upon their own earnings. This implies that slightly over half of current female retirees receiving Social Security retirement benefits are affected by auxiliary benefit rules. ${ }^{9}$ Larger percentages of women are affected on a lifetime basis, as most married women will shift from their own retirement benefit to a widow's benefit based on their husband's earnings upon the death of their husband. ${ }^{10}$ Thus, Social Security auxiliary benefit rules can potentially have far-reaching effects on the work incentives presented to women over the course of their lives.

\section{Net tax rates}

Social Security's treatment of different individuals can be measured in several ways. The most basic is (1) the replacement rate, which expresses Social Security benefits as a percentage of pre-retirement earnings but does not directly measure lifetime receipts of taxes or benefits. Lifetime money's worth measures include (2) the internal rate of return, which is akin to the

\footnotetext{
${ }^{8}$ See Reznik, Weaver, and Biggs (2009).

${ }^{9}$ Institute for Women's Policy Research. 2005. Drawn from Annual Statistical Supplement 2004, Tables 5.A1.1 through 5.A1.4, and Table 5.G1. (Washington, DC: Social Security Administration). ${ }^{10}$ This occurs because the spousal benefits creates an infra-marginal distortion to labor supply, since the lower-earner would have received the spousal benefit even if she had not earned any income over her lifetime.

${ }^{10}$ This occurs because the spousal benefits creates an infra-marginal distortion to labor supply, since the lowerearner would have received the spousal benefit even if she had not earned any income over her lifetime.
} 
interest rate paid on an investment, and (3) the benefit-to-tax ratio, which divides the present value of lifetime benefits by the present value of lifetime taxes.

This paper uses a measure known as the net tax rate. The net tax rate divides an individual's lifetime taxes paid net of lifetime benefits received by the individual's lifetime earnings. That is,

$$
\mathrm{NTR}=\frac{(P V \text { taxes }-P V \text { benefits })}{P V \text { lifetime taxable earnings }}
$$

All figures are presented in present value terms, meaning that taxes, benefits and earnings are discounted at the Social Security trust fund interest rate (usually a nominal value of around 5.7 percent) to make cash flows taking place at different times more comparable. ${ }^{11}$ In addition, following convention, both the employer and the employee share of the Social Security payroll tax are attributed to the employee.

To illustrate this measure, imagine that Mrs. Smith paid \$200,000 in Social Security taxes over her lifetime and received $\$ 180,000$ in lifetime benefits, for a net value of $\$ 20,000$. Her lifetime earnings are $\$ 2,000,000$. Thus, her net tax rate is 1 percent of lifetime earnings.

This measure requires some interpretation. The net tax rate measures the tax paid or subsidy received by an individual over his or her lifetime. If an individual's lifetime taxes and benefits were equal in value, the lifetime net tax rate would be zero. That is, their entire payroll tax could be viewed as a "contribution" which was returned in full through benefit payments. An individual whose taxes exceeded her benefits paid a "tax" that was not returned. Likewise, a person whose benefits exceed their taxes received a "subsidy" from the program. The value of the net tax rate indicates the size of the tax paid or subsidy received.

The net tax rate measures the overall treatment of an individual by the Social Security program. In some cases, however, it does not accurately measure the impact of the program on individuals' labor supply incentives. This can occur when an individual receives spousal or widow benefits or when an individual generates such benefits for receipt by a spouse. In these cases, the link between taxes paid and benefits received may differ from that which would

\footnotetext{
${ }^{11}$ The Social Security trust funds are credited with an interest rate equal to the average market yield on marketable interest-bearing securities of the Federal government that are not due or callable for at least 4 years.
} 
ordinarily be inferred from traditional net tax rate measures. A married woman receiving spousal or widow's benefits receives benefits that were not generated by her own taxes; likewise, a husband whose spouse or former spouse receives spouse or widow benefits may generate benefits that are not reflected in measures of his own benefit receipts.

To account for these differences, this study utilizes a second net tax rate measure to analyze the incentives presented to women by Social Security, the generated net tax rate. The generated net tax rate is calculated somewhat differently for the lower-earning spouse in a couple than for the higher-earning spouse in a couple. The generated net tax rate for the lower-earning spouse is calculated based on the lifetime benefits generated by an individual's own lifetime tax payments, net of lifetime taxes paid; and is represented as a percentage of lifetime earnings. The generated net tax rate for the higher-earning spouse captures both the lifetime benefits the higher-earning spouse earns for himself and the lifetime spousal and survivors benefits he generates for his spouse. Thus, the generated net tax rate for the lower-earning spouse in a couple equals :

$$
G N T R_{l}=\frac{(P V \text { taxes })-[(P V \text { benefits })-(P V \text { benefits received if never worked })]}{(P V \text { lifetime taxable earnings })}
$$

For this lower-earning spouse, the generated net-tax rate is a function of the benefits she could receive based on her own earnings record, net of those she is eligible for based upon her spouse's earnings.

The generated net tax rate for the higher-earning spouse in a couple equals:

$$
\begin{aligned}
& G N T R_{\square} \\
& =\frac{(P V \text { taxes })-[(P V \text { benefits received })+(P V \text { benefits paid to spouse as if spouse never worked })]}{(P V \text { lifetime taxable earnings })}
\end{aligned}
$$

For a higher-earning spouse, the generated net tax rate reflects the auxiliary benefits his earnings could generate for a current or former spouse or a widow, in addition to the benefits received by the individual himself. Thus, while the generated net tax rate will be higher than the ordinary net tax rate for the lower-earning spouse, it will be lower than the conventional net tax rate for the higher-earning spouse. 
The generated net tax rate will focus on incentives to participate in the labor force for married individuals. When auxiliary benefits enter the picture - as they do for a majority of women over their lifetime - the traditional net tax rate cannot be interpreted for the purposes of judging labor force incentives in the same way that an ordinary tax rate might. The generated net tax rate is designed to provide a partial measure of the incentives presented to married women that would be more comparable to ordinary tax rates used in analyses not focused on the Social Security program. ${ }^{12}$ For most of the paper, we apply the generated net tax rate for the lowerearning spouse to calculate the generated net tax rate for married women and assume that married women are generally secondary earners in a household; this is not true in all cases, and when a husband is the secondary earner conclusions drawn for married women may apply to married men.

\section{Example using stylized earners}

The following examples use stylized earnings patterns developed by Social Security’s Office of the Chief Actuary to illustrate the basic concept of the net tax rate and the generated net tax rate. Once done, more detailed microsimulation data from SSA's MINT model will be used. We will refer to the husband as the high earner and the wife as the low earner, as this is by far the most common circumstance. However, we note that Social Security's benefit formula is gender-neutral and the results would be the same if husband and wife earnings were reversed. ${ }^{13}$

To illustrate, assume that Mr. Smith earns around 200 percent of the average wage throughout his life while Mrs. Smith, either due to a low wage rate or time out of the workforce, earns 50 percent of the average wage. For each case, lifetime earnings are simulated and Social Security benefits are calculated as of age 66, the full retirement age as of 2010. These benefits extend through retirement, and are adjusted for annual Cost of Living Adjustments and the probability of death. Present value of lifetime taxes, benefits, and earnings are calculated using a nominal discount rate of 5.7 percent (the Social Security trust fund interest rate). These figures allow us to calculate traditional and generated net tax rates for each spouse.

\footnotetext{
${ }^{12}$ In addition to affecting marginal returns to work, the presence of auxiliary benefits may also have an income effect, although this effect is not analyzed here.

${ }^{13}$ Current data suggest that nearly one-third of married women earn more than their spouses, so we can expect more married men to face the spousal benefit over time.
} 


\begin{tabular}{|c|c|c|c|c|}
\hline & \multicolumn{2}{|c|}{ Own taxes/benefits } & \multicolumn{2}{|c|}{ Net benefits generated by } \\
\hline & Husband & Wife & Husband & Wife \\
\hline PV taxes & $\$ 45,262$ & $\$ 11,315$ & $\$ 45,262$ & $\$ 11,315$ \\
\hline PV benefits & $\$ 29,754$ & $\$ 14,877$ & $\$ 44,631$ & $\$$ \\
\hline Net tax & $\$ 15,508$ & - \$3,562 & $\$ 631$ & $\$ 11,315$ \\
\hline PV earnings & $\$ 396,976$ & $\$ 99,244$ & $\$ 396,976$ & $\$ 99,244$ \\
\hline Net tax rate & $3.9 \%$ & $-3.6 \%$ & $0.2 \%$ & $11.4 \%$ \\
\hline
\end{tabular}

Table 1 shows the results for these stylized earners. When net tax rates are calculated using all taxes paid and all benefits received, Social Security is found to be progressive as expected. Mr. Smith pays $\$ 45,262$, or 11.4 percent of his earnings, in taxes over his lifetime. ${ }^{14}$ ( Mr. Smith collects $\$ 29,754$, or 7.5 percent of his lifetime earnings, in lifetime benefits. The difference constitutes the next tax rate of 3.9 percent. To a first approximation, the 3.9 percent net tax rate (rather than the statutory 11.4 percent rate) characterizes the labor supply incentive effects of Social Security.

Mrs. Smith, on the other hand, pays $\$ 11,315$, or 11.4 percent of her earnings, in taxes over her lifetime. She can expect to receive $\$ 14,877$ in lifetime benefits (which includes 50 percent of the husband's benefit as a spousal benefit), which equals 15.0 percent of her lifetime earnings. Her lifetime net tax rate therefore is -3.6 percent of earnings. Mrs. Smith receives a subsidy from the Social Security program.

We next calculate net tax rates based on the benefits generated by taxes paid. The generated net tax rate for Mr. Smith counts the benefits he receives from his own earnings record plus the auxiliary benefit he generates for Mrs. Smith. The generated net tax rate for Mrs. Smith includes the benefits she could receive based on her own earnings record net of the auxiliary benefits she could receive based on Mr. Smith’s earnings.

\footnotetext{
${ }^{14}$ This figure is below the current statutory rate of 12.4 percent because tax rates increased over the course of this individual's working lifetime.)
} 
In this scenario, Mr. Smith’s $\$ 45,262$ in lifetime taxes generate $\$ 29,754$ in benefits for himself plus a $\$ 14,877$ lifetime auxiliary benefit for Mrs. Smith, for a total of $\$ 44,631$. This leads to a -0.2 percent generated net tax rate, lower than his 3.9 percent net tax rate.

Mrs. Smith pays $\$ 11,315$ in lifetime taxes. But her own benefit is no greater than what she would have received had she not worked at all (because of the auxiliary benefit paid from her

husband's earnings record), so her taxes do not generate any additional benefits for herself. ${ }^{15}$ Her generated net tax rate equals the statutory tax rate of 11.4 percent. From this point of view, her incentives to work could be worse than her husband's and worse than would be implied by the traditional net tax rate measure.

In practice, generated net tax rates are far more nuanced. A wife may initially collect retirement benefits based upon her own earnings record, implying lower generated net tax rates. Upon the death of her husband, however, she might shift to a widow's benefit based upon her husband's earnings record, which implies a high generated net tax rate;.

\section{Background on the MINT model}

This section utilizes the SSA's MINT model to measure net tax rates for Social Security participants in birth cohorts beginning with participants born in the 10-year period from 19311940 (referred to as the 1940 cohort) through participants born in the 10-year period from 19811990 (referred to as the 1990 cohort). MINT matches individual responses to the U.S. Census Bureau's Survey of Income and Program Participation (SIPP) to Social Security earnings records to create a large, comprehensive and detailed database of individual earnings and demographic information. The matched data are used to project a person's future earnings, marital status changes, disability incidence, date of retirement, Social Security benefit, and other retirement income. The current version of the MINT model (MINT 5) is calibrated to the projections contained in the 2008 Social Security Trustees Report. ${ }^{16}$

The MINT model has many strengths, but it also has limitations. Its particular strength in this context is linking of spousal earnings and benefits records, which allows us to calculate

\footnotetext{
${ }^{15}$ During the retirement period in which both she and Mr. Smith are alive, she will rely on a benefit derived from his earnings record. If Mr. Smith precedes her, she will then receive his benefit as his widow.

${ }^{16}$ Additional information on the MINT model can be found in Smith, et al, 2007.
} 
benefits generated by a spouse's earnings rather than that of the individual. However, MINT's labor force participation is not, in general, dynamic with regard to changes in Social Security policy; the model does not predict changes in labor force participation due to policies that affect generated net tax rates. The model also does not allow us to incorporate joint labor supply decisions of spouses. This is particularly important because the Program's incentives may affect the allocation of labor within the household. For example, couples who have similar earnings may decide it is optimal for one spouse to be the primary earner while the other exits from the labor market entirely. In addition, the model does not allow us to consider the multiple margins along which labor supply responds, such as whether to retire- either fully or partially.- These types of responses can be considered through structural models; see for example Gustman and Steinmeier (2009) with regard to the retirement decision.

\section{Note on changing statutory tax rates}

Net tax rates are initially reported for members of the 1940 birth cohort in order to present a cross sectional view of incentives presented by the Social Security program. Later, projected trends over subsequent birth cohorts are presented to show how such incentives may change over time.

To provide context regarding historical net tax rates, it should be understood that payroll tax rates were lower in the past than the current 12.4 percent total employer and employee rate (See Figure 1). 


\section{Figure 1.}

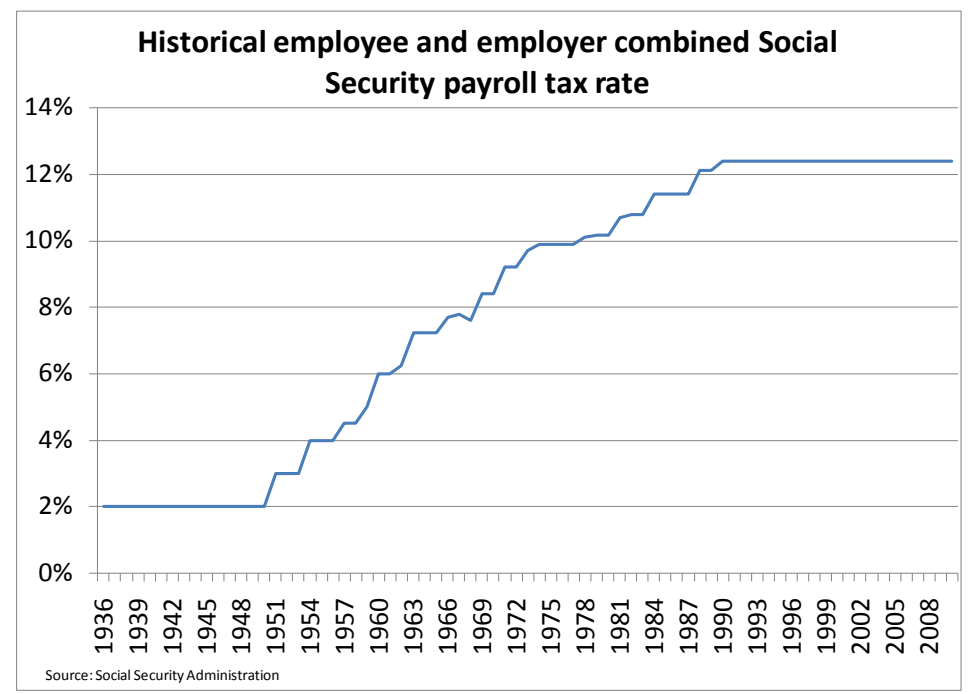

The figure shows someone born in 1940, who worked from 1961 through 1995, would have faced an average statutory tax rate of 10.5 percent. The lifetime statutory tax rate, however, would be calculated as the present value of lifetime taxes relative to the present value of lifetime earnings and thus would differ from person to person based upon the timing of their earnings.

\section{Net tax rate results for the 1940 birth cohort}

Table 2 illustrates the distribution of net tax rates among the 1940 birth cohort. As a whole, the 1940 cohort of workers paid a net tax rate of -1.07 percent, indicating that they received benefits that exceeded their full tax contributions by just over 1 percent of lifetime earnings. Females paid a net tax rate of -8.18 percent, indicating that they received lifetime benefits less than double their lifetime taxes. ${ }^{17}$ Males, by contrast, paid a net tax rate of 2.75 percent, indicating that they did not receive benefits equal to the full statutory tax rate they paid.

\footnotetext{
${ }^{17}$ While the current Social Security tax rate is 12.4 percent of earnings, rates were lower than this level through the mid-1980s.
} 


\begin{tabular}{|l|r|}
\hline \multicolumn{2}{|c|}{$\begin{array}{c}\text { Table 2. Net tax rates, 1940 birth cohort } \\
\text { (figures are medians) }\end{array}$} \\
\hline Group & $\begin{array}{r}\text { Rate } \\
(\%)\end{array}$ \\
\hline All & -1.07 \\
\hline Gender & -8.18 \\
\hline Female & 2.75 \\
\hline Male & -7.18 \\
\hline Lifetime shared earnings quintile & -4.67 \\
\hline Lowest & -1.62 \\
\hline $2^{\text {nd }}$ & 0.29 \\
\hline Middle & 2.04 \\
\hline $4^{\text {th }}$ & \\
\hline Highest & -9.63 \\
\hline Women & -0.79 \\
\hline Married & \\
\hline Unmarried & \\
\hline Source: MINT model, authors' calculations. \\
\hline
\end{tabular}

Net tax rates by lifetime earnings show the expected progressivity of the benefit structure. The lowest-earning quintile, measured by shared lifetime earnings, paid a net tax rate of -7.18 percent; the middle quintile paid a net tax rate of -1.62 percent, while the highest earning quintile paid a positive net tax rate of 2.04 percent. $^{18}$

Before we discuss the results for married women, it is useful to describe how "married" individuals are identified. We define "married" as anyone who has had a marriage that lasted at least 10 years, the point at which a spouse become eligible for spousal benefits in the case of divorce. ${ }^{19}$ ) The data show married women paid significantly lower net tax rates than did unmarried women in the 1940 birth cohort. Married women in the 1940 birth cohort paid a median net tax rate of -9.63 percent of lifetime earnings, while unmarried women paid a net tax rate of -0.79 percent. In part, this would be due to the generally lower lifetime earnings of married versus unmarried women, but is also undoubtedly due to eligibility for spousal and survivors benefits. When net tax rates for married women are calculated based only on worker

\footnotetext{
${ }^{18}$ Progressivity is also indicated by education level, albeit on a more muted scale.

${ }^{19}$ For the 1940 cohort, 92 percent of women had at least one 10 year or more marriage and 69 percent were married only once. For men, 93 percent had at least one 10 year or more marriage and 60 percent were only married once. For the overall sample (the 1940 cohort through the 1990 cohort), 84 percent of women had at least one 10 year or more marriage and 61 percent were married only once. For men, 85 percent had at least one 10 year or more marriage and 55 percent were only married once.
} 
benefits - that is, benefits that would be payable based on the individual's own earnings, absent auxiliary benefits - the median value for the 1940 cohort is -1.45 percent. This is presumably due to the lower lifetime earnings of married versus single women. But this figure also indicates that auxiliary benefits for the median married woman in this group were worth approximately 8.2 percent of lifetime earnings.

As we noted above, however, the overall treatment of participants by the Social Security program does not illustrate the program's impact on their work incentives. This occurs because of benefits generated by spouses' earnings. In the next section, we present generated net tax rates showing work incentives.

\section{Generated net tax rate results for the 1940 birth cohort}

As noted above, in these calculations an individual is counted as "married" if he or she had a marriage that lasted at least 10 years, as this would entitle them to generate or receive benefits with regard to a former spouse. Thus, “married” individuals in this sample may not necessarily be married at the time of retirement, but simply had a marriage last long enough to potentially generate spousal or widows' benefits. This test is designed as a filter to isolate individuals who may be eligible for auxiliary benefits from those who are not, although given the complexity of the Social Security benefit formula, it is an imperfect filter.

Figure 2 depicts the distribution of generated net tax rates for married and unmarried women in the 1940 birth cohort. Generated net tax rates are higher for married women than unmarried women in almost all percentiles of the distribution. The median married woman in the 1940 birth cohort paid a generated net tax rate of 7.5 percent of earnings, versus a 1.1 percent generated net tax rate for the median unmarried woman. Nearly half of unmarried women have negative generated tax rates, implying that for such individuals the Social Security program as a whole - benefits net of taxes - constitutes an incentive to work. Notably, we find almost no married women with negative generated net tax rates; even at the $10^{\text {th }}$ percentile, the generated net rate for married women is 2 percent of earnings. ${ }^{20}$

\footnotetext{
${ }^{20}$ The distribution of generated tax rates involves several countervailing factors, in addition to the relative lifetime earnings of the spouses. An individual who lives longer will pay a lower generated net tax rate, so long as any benefits are generated based upon her own earnings. At the same time, longer life spans are associated with a greater likelihood of receiving widows' benefits, which tend to increase generated net tax rates.
} 
Figure 2.

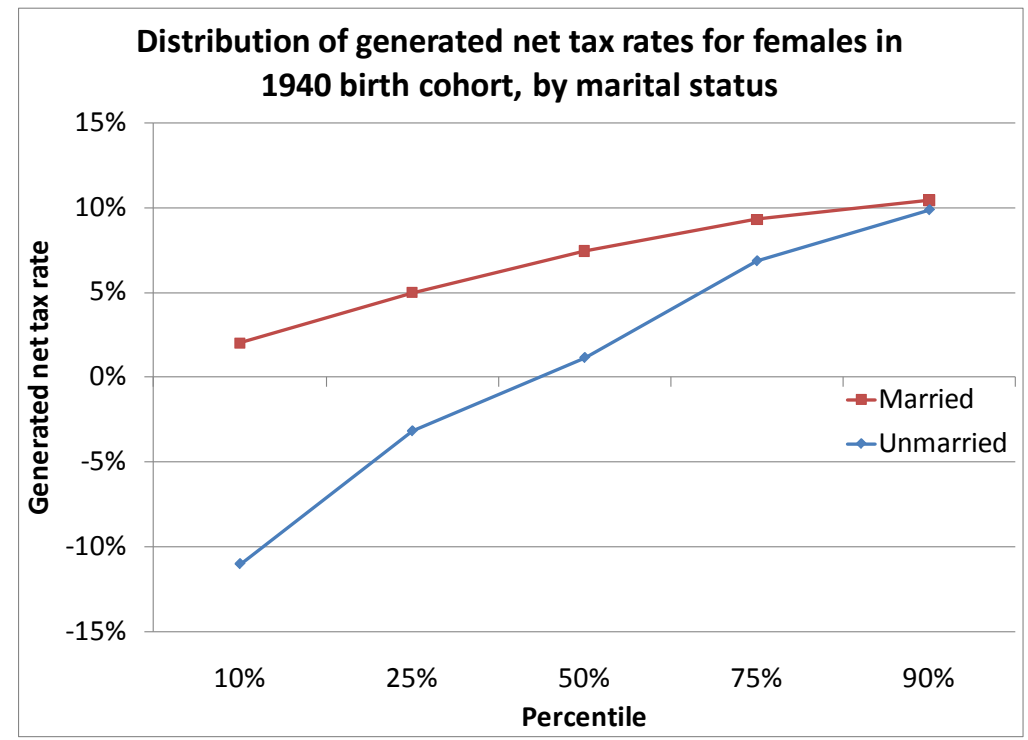

\section{Generated net tax rates over time}

Differences in generated net tax rates between married and unmarried women grow larger in the 1971-1980 birth cohorts (referred to as the 1980 cohort) shown in Figure $3 .^{21}$ At the median, married women in the 1980 birth cohort pay a generated net tax rate of 10.2 percent of earnings, higher than the 7.5 percent paid by the 1940 birth cohort.

\footnotetext{
${ }^{21}$ Bear in mind that much of the earnings and life events, such as marriage and divorced for the 1980 cohort are projected.
} 


\section{Figure 3.}

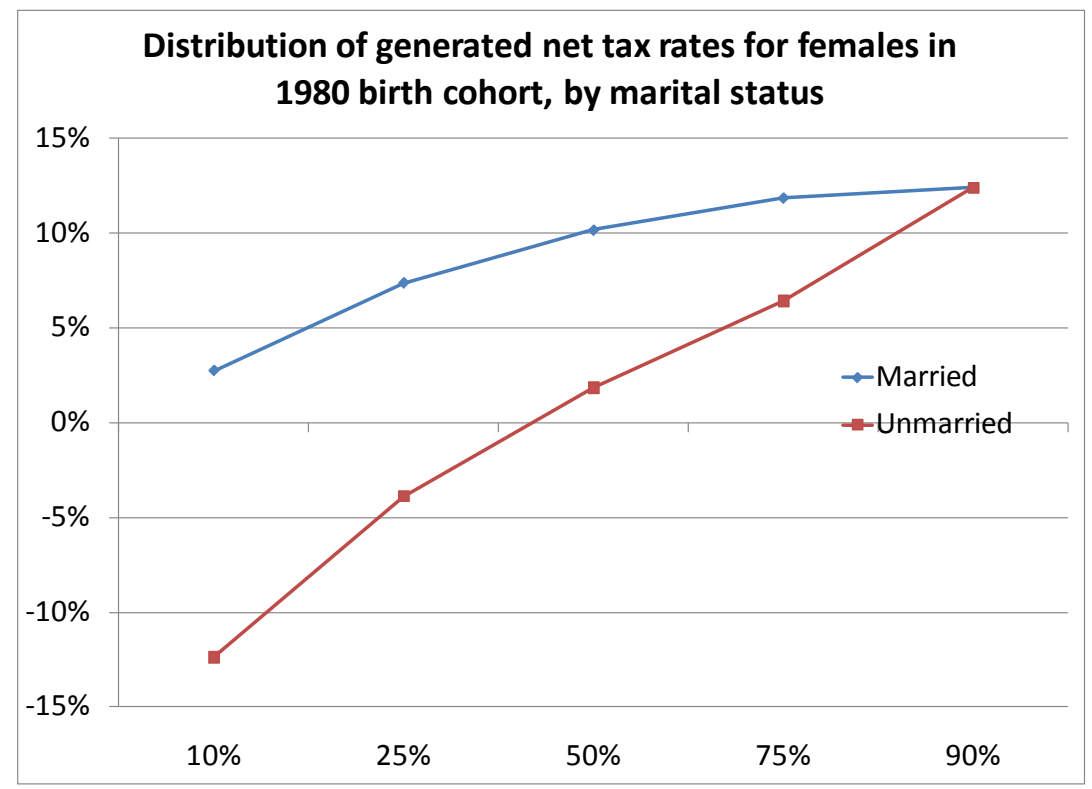

These results may seem counterintuitive given rising female earnings, which should result in more women receiving retirement benefits based upon their own earnings records. This trend might be expected to reduce generated tax rates for women. While lower generated net tax rates may occur in some cases, in many other cases higher female earnings may actually increase generated net tax rates. ${ }^{22}$ For women who already receive a benefit based on their own earnings either unmarried women or married women with earnings sufficient to generate a worker benefit in excess of an auxiliary benefit - higher earnings will tend to increase generated net tax rates due to the progressive structure of the benefit formula. For women who receive an auxiliary benefit, increased earnings may produce a lower generated net tax rate only once earnings have reached a level sufficient to eliminate eligibility for auxiliary retirement or widow benefits. In the intervening space between initial earnings and the level necessary to eliminate auxiliary benefit eligibility, however, higher earnings for women currently receiving auxiliary benefits produce higher taxes but not higher benefits.

These results seem to indicate that in earlier cohorts the typical married woman had earnings far below the level necessary to generate a benefit based on her own earnings rather than those of a spouse. If so, then married women's earnings could rise significantly before any

\footnotetext{
${ }^{22}$ Rising women's earnings may also lead to many more dually entitled spouses who would have poor generated net tax rates.
} 
additional benefits were generated, since earnings would have to rise enough for a woman's benefit to be over half the value of her husband's benefit. The taxes paid based on these increased earnings would be a "pure tax" that produced no additional benefits, thereby increasing generated net tax rates.

There is an additional trend to be aware of as well: that of higher statutory Social Security payroll tax rates and higher traditional net tax rates. As noted above, the combined employer/employee Social Security payroll tax rate has increased from 6 percent in 1960 - when many members of the 1940 birth cohort might be expected to enter the workforce - to 12.4 percent of earnings today, a rate assumed to continue into the future. ${ }^{23}$ This tax increase largely accounts for increases in traditional net tax rates. While replacement rates - that is, the ratio of benefits to pre-retirement earnings - have remained relatively stable over time, the tax required to maintain these replacement rates has risen significantly and can be expected to continue to increase over time. The median traditional net tax rate for all participants will rise from -0.77 percent for members of the 1940 birth cohort to 1.98 percent for members of the 1990 cohort, even assuming the program remains able to pay scheduled benefits at current tax rates. Along this line, as reforms are implemented to maintain Social Security’s long-term financing, net tax rates will likely increase further.

In the future, relatively fewer female retirees are expected to rely on a spouse for part or all of their lifetime Social Security benefits, but for those who do, generated net tax rates will be significantly higher than for a similar woman in earlier birth cohorts. This occurs because statutory Social Security tax rates will also be significantly higher. Thus, while the trend toward higher female earnings and greater reliance on worker benefits will tend to reduce generated net tax rates, the trend toward higher taxes and higher traditional net tax rates more than offsets this reduction.

Figure 4 illustrates the distribution of generated net tax rates for married women in the 1940 through 1990 10-year birth cohorts. The increase in generated net tax rates is striking. At the median, the rate rises from 7.5 percent of earnings for the 1940 cohort to 10 percent for the 1961-1970 cohort (1970 cohort). Rates level off thereafter, although policies to maintain

\footnotetext{
${ }^{23}$ These calculations do not account for Social Security solvency issues, which could be expected to increase both traditional and generated net tax rates for affected cohorts.
} 
program solvency would be expected to increase them further. In addition, a larger share of married women is projected to pay high generated net tax rates over time. For instance, 25 percent of married women in the 1940 birth cohort paid generated net tax rates above 9.3 percent. Despite projected increases in the earnings of married women, by the 1970 cohort half of married women will pay generated net tax rates in excess of 10 percent.

Figure 4.

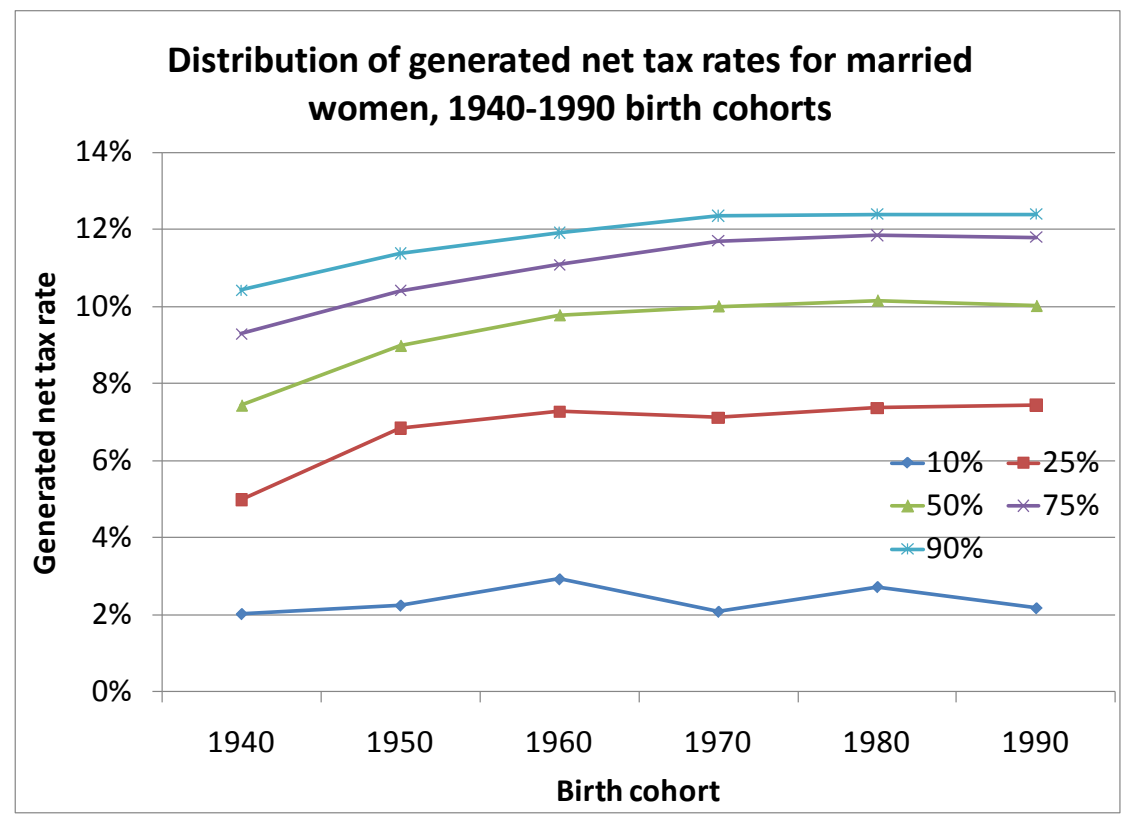

Despite their more favorable general treatment by the Social Security program, married women are often presented with disincentives to engage in the labor force due to Social Security’s auxiliary benefit provisions. Moreover, contrary to initial perceptions based on the rising earnings of married women, these disincentives are expected to grow larger in coming decades.

\section{Generated net tax rates for married men}

The corollary of married women paying generated net tax rates well in excess of their ordinary net tax rates is married men paying generated tax rates well below the conventional net tax rate measure. While the focus of this study is on generated net tax rates for married women, these measures are calculated below for married men. The generated net tax rates in this section 
are calculated for individuals married only once in order to define the higher-earning spouse and the lower-earning spouse in the couple. ${ }^{24}$

Figure 5 illustrates the distribution of generated net tax rates for married men in the 1940 birth cohort, with generated net tax rates for women in the same cohort included for reference. At the median, married men have a generated net tax rate of -1.2 percent of lifetime earnings. This compares to a median generated net tax rate of 7.5 percent for married women in that birth cohort.

\section{Figure 5}

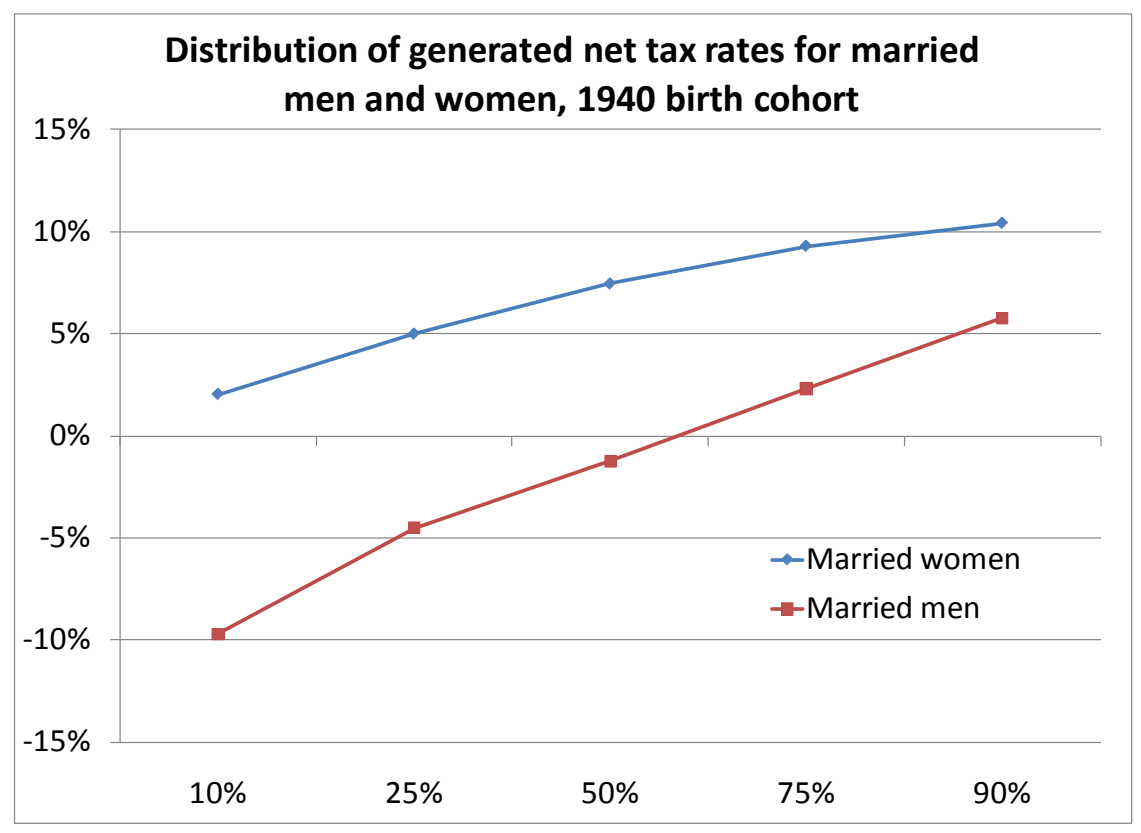

Put another way, Social Security is more than actuarially fair in its treatment of the typical married male if one considers the benefits men's taxes generate for their spouses in addition to the benefits paid to them. One-quarter of married men in the 1931-40 birth cohort paid generated net tax rates of less than -4.5 percent of lifetime earnings while one-tenth pay net

\footnotetext{
${ }^{24}$ Higher (lower) earning spouses are married individuals whose present value of their lifetime earnings are greater (less) than the present value of their spouse's lifetime earnings. For the 1940 cohort, of married women and men who were married only once, 18 percent of the wives and 82 percent of the husbands were the higher-earning spouse. For the overall sample (the 1940 cohort through the 1990 cohort), 27 percent of the wives and 73 percent of the husbands were the higher-earning spouse. "Married" is defined as having had a marriage of a duration of 10 years or more.
} 
tax rates of less than -9.7 percent. This makes the incentives to participate in the labor force greater for men than they would appear under ordinary net tax rate measures.

This median generated net tax rate of -1.2 percent for married men born in 1940 can also be compared to a median conventional net tax rate of 2.1 percent for men in that cohort. The difference between the two indicates that the typical married male generates auxiliary benefits for his spouse equal to approximately 3.3 percent of the husband's lifetime earnings, a significant sweetener over his treatment as expressed under conventional net tax rate measures.

\section{Discussion and conclusions}

In this paper, we constructed a new measure of the treatment of Social Security of married women, the "generated" net tax rate, and contrasted it to the traditional net tax rate used in the literature. We also examined the generated tax rates for married women in several birth cohorts whose labor market participation was increasing. Traditional net tax rates present a fuller picture of individuals' overall treatment by the Social Security program than other measures, such as the replacement rate, since net tax rates represent the difference between taxes and benefits as a percentage of lifetime earnings. When assessing the incentives to participate in the labor force presented by the Social Security program, however, traditional net tax rates cannot generally be treated analogously to ordinary income or other tax rates.

Social Security’s auxiliary benefits for spouses and widows can imply a substantial tax for the lower-earning spouse in a household, because their earnings and tax contributions may generate little or sometimes no additional benefits. In these cases, the generated net tax rate, which accounts for the effects of auxiliary benefits, is likely a better measure of a married woman's incentives to work and contribute to the program. These generated net tax rates are often significantly higher than traditional tax rates. And despite rising female earnings, which should increase the percentage of women claiming benefits on their own earnings records and reduce the share of total benefits paid as auxiliary benefits, generated net tax rates are likely to increase in the future. These higher effective tax rates will tend to worsen incentives to participate in the labor force.

We find that married men pay generated net tax rates significantly below their traditional net tax rates, however. This is due to the auxiliary benefits their earnings can generate for a 
spouse. While median generated net tax rates for men are projected to rise, from -1.2 percent for the 1940 birth cohort to 1.1 percent of earnings for the 1990 cohort, these increases, and their expected effects on incentives to work, are modest relative to those for women.

All of that said, these results should be considered with one significant caveat: as the average age of marriage has increased and the share of marriages ending in divorce have risen, a woman faces significant uncertainty regarding how her earnings in any given year may affect her lifetime benefits. In earlier times, when marriages occurred early in life and only rarely dissolved, an expected generated net tax rate for a married woman could be predicted with reasonable certainty and would constitute a significant disincentive to engage in paid work. In 1960, the median first marriage for women occurred at age 20, leaving relatively little time for paid work prior to getting married. By 2003, the median value had risen to over age 25 and for educated women with the highest potential earnings marriages were delayed further. Thus, women today have more significant earnings prior to marriage and, due to higher rates of divorce, have a greater likelihood of needing to rely upon their own earnings to support themselves both in the present and, through saving and contributing to Social Security, in retirement.

The figures presented in this paper show a widening dispersion of generated net tax rates among all women - from an interquartile range of 4.7 percent of earnings for all women in the 1940 birth cohort to 6.7 percent of earning for the 1990 cohort, - but it is not clear that uncertainty regarding future marital conditions should cause an individual to ignore trends in generated net tax rates and their implications for labor force participation and investment in human capital.

Finally, we note two commonly proposed reforms to lower generated net tax rates and improve incentives to work outside the home that could have important implications in this area. The first proposal would cap spousal benefits for high earning households, such that the maximum spousal benefit could be no higher than a given level. This would tend to improve incentives for married women to work by increasing benefit increases relative to increased earnings and contributions. (In addition, a spousal cap would reduce benefits, a negative income effect that would provide a secondary incentive for increased paid work.) 
A second reform proposal that might lower generated net tax rates is proposed increases in widow's benefits to 75 percent of the total benefits received by the couple when both spouses were alive. Under current law, a widow would receive the higher of her own worker benefit or that of her deceased spouse, but not both. As the husband generally has a higher worker benefit, this provision fails to reward a married woman for her earnings and thereby increases generated net tax rates. If widow's benefit were increased to 75 percent of the couple's total benefit, this would produce a widow's benefit that, in some cases at least, would in part depend on the earnings of the wife. In cases where the wife received a spousal benefit while her husband was alive, the increased widow's benefit would have no effect on generated net tax rates. However, in cases where a married woman relied on an earned benefit while her husband was alive but shifted to a widow's benefit upon the death of her spouse, this provision may lower generated net tax rates for married women.

Given the need to increase labor force participation in the United States as the population ages, the effects of the Social Security benefit structure and the associated generated net tax rates on married women merit much further study. 


\section{References}

Butrica, Barbara A., Johnson, Richard W., Smith, Karen E. and Steuerle, C. Eugene, Does Work Pay at Older Ages (November 2004).

Cohen, Lee, Eugene Steuerle, and Adam Carasso. 2004. "Redistribution Under OASDI: How Much and to Whom?” In K. Buto, M. Priddy Patterson, W. E. Spriggs, and M. Rockeymoore, eds. Strengthening Community: Social Security in a Diverse America. Washington, DC: Brookings Institution Press.

Congressional Budget Office. “Effective Marginal Tax Rates on Labor Income.” November 2005.

Goda, Gopi Shah, Slavov, Sita N. and Shoven, John B. "Removing the Disincentives in Social Security for Long Careers” (May 2007). NBER Working Paper Series, Vol. w13110.

Gustman, Alan L., and Thomas L. Steinmeier. 2000. "How Effective Is Redistribution Under the Social Security Benefit Formula?” Paper presented at the Second Annual Joint Conference for the Retirement Research Consortium, Washington, D.C., May 17-18.

Gustman, Alan L., and Thomas L. Steinmeier. 2009. “Integrating Retirement Models.” NBER Working Paper No. 15607, December 2009.

Institute for Women’s Policy Research. "Women and Social Security: Benefit Types and Eligibility.” Briefing Paper \#ZD463. June 2005. Drawn from Annual Statistical Supplement 2004, Tables 5.A1.1 through 5.A1.4, and Table 5.G1. (Washington, DC: Social Security Administration)

Reznik, Gayle, Weaver, David A. and Biggs, Andrew G. "Social Security and Marginal Returns to Work Near Retirement “(April 15, 2009). Social Security Administration, Issue Paper No. 2009-02.

Sabelhaus, John. "What is the effective Social Security tax on additional years of work?" National Tax Journal. September, 2007.

Smith, Karen, Eric Toder, and Howard Iams. 2003/2004. "Lifetime Distributional Effects of Social Security Retirement Benefits.” Social Security Bulletin 65(1): 33-61.

Smith, Karen, Melissa M. Favreault, Caroline Ratcliffe, Barbara Butrica, Eric Toder and Jon Bakija. "Final Report: Modeling Income in the Near Term 5." The Urban Institute. October 2007.

Social Security Administration. "Your Retirement Benefit: How It Is Figured." SA Publication No. 05-10070, January 2010.

U.S. Census Bureau, Annual Social and Economic Supplement: 2003 Current Population Survey, Current Population Reports, Series P20-553, "America's Families and Living Arrangements: 2003." 


\section{RECENT WORKING PAPERS FROM THE}

\section{CENTER FOR RETIREMENT RESEARCH AT BOSTON COLLEGE}

What is the Impact of Foreclosures on Retirement Security?

Irena Dushi, Leora Friedberg, and Anthony Webb, November 2010

Children and Household Utility: Evidence from Kids Flying the Coop

Norma B. Coe and Anthony Webb, November 2010

Overview of the CRR 2009 Retirement Survey

Alicia H. Munnell, Norma B. Coe, Kelly Haverstick, and Steven A. Sass, October 2010

State Wage-Payment Laws, the Pension Protection Act of 2006, and 401(k) Saving

Behavior

Gary Engelhardt, October 2010

Asset Cycles and the Retirement Decisions of Older Workers

Jan Ondrich, October 2010

Price Deflators, the Trust Fund Forecast, and Social Security Solvency

Barry Bosworth, October 2010

The Impact of a DROP Program on the Age of Retirement and Employer Pension Costs Samson Alva, Norma B. Coe, and Anthony Webb, September 2010

Housing Consumption in Late Life: The Role of Income, Health Shocks, and Marital Shocks

Douglas A. Wolf and Janet M. Wilmoth, September 2010

Adjusting Social Security for Increasing Life Expectancy: Effects on Progressivity Courtney Monk, John A. Turner, and Natalia A. Zhivan, August 2010

Work and Retirement Patterns for the G.I. Generation, Silent Generation, and Early Boomers: Thirty Years of Change

Richard W. Johnson, Barbara A. Butrica, and Corina Mommaerts, July 2010

Spousal Health Shocks and the Timing of the Retirement Decision in the Face of ForwardLooking Financial Incentives

Courtney Harold Van Houtven and Norma B. Coe, June 2010

Incorporating Employee Heterogenity Into Default Rules for Retirement Plan Selection Gopi Shah Godi and Colleen Flaherty Manchester, May 2010

Accurately Measuring Health Over the Life Course

Fabian Lange and Doug McKee, May 2010

All working papers are available on the Center for Retirement Research website (http://crr.bc.edu) and can be requested by e-mail (crr@bc.edu) or phone (617-552-1762). 